\title{
On refining hypotheses for biased sex ratios and aposematic polymorphism in African butterflies: a commentary
}

\author{
David A.S. Smith \\ David A.S. Smith (davidassmith@btinternet.com), Natural History Museum, Eton College, Windsor, SL4 6EW, \\ United Kingdom
}

Idris and Hassan (2013) are surely right to emphasize that aposematic species and especially those involved in Müllerian mimicry complexes are expected to be (and usually are) monomorphic. Thus, the three species under discussion, Danaus chrysippus, Acraea encedon and A. encedana are paradoxical because they are in many populations (though by no means all) polymorphic. In fact, D. chrysippus is monomorphic through most of its vast range, even in Africa, and invariably so in Asia and Australia; the authors do not acknowledge this. It is the restriction of D. chrysippus polymorphism in East Africa that is especially paradoxical. Acraea encedon is monomorphic in extreme West Africa (Senegal \& Gambia) and A. encedana is monomorphic throughout West Africa.

Some predators are able to generalize over several different prey types that may be adjudged polymorphic to the human eye (Duncan \& Sheppard 1965) and there are many examples of 'jack of all trades' mimicry, especially among syrphid flies and their hymenopteran models (Edmunds 2000; Penney et al. 2012). It is wise to acknowledge that the eyes of humans and butterfly predators, especially birds, differ profoundly and that non-visual attributes such as flight behaviour and olfactory cues are also used by predators.

The manipulative influence of early male-killing endosymbionts on their hosts is correctly described by the authors. In particular, infected females should have a fitness advantage over uninfected ones through reduced sibling competition for resources and the opportunity to cannibalize male eggs, as occurs routinely in ladybird beetles (Majerus, 1994). The high efficiency of its matrilineal vertical transmission is the other factor integral to the success of the endosymbiont. In batch layers such as the two Acraeas, the proximity of eggs facilitates cannibalism of their dead brothers by females but whether it could occur on a regular basis in $D$. chrysippus is more problematical as this butterfly has always been thought to scatter its eggs widely, and even to be deterred from laying eggs on a leaf already occupied by an egg or caterpillar. However, Smith (2013) - in fairness, a publication that Idris and Hassan cannot have seen-shows that, if presented with a choice between host plants growing in patches or as isolates, D. chrysippus much prefers the latter. The overloading of isolated plants with eggs is a scenario in which the benefits of male-killing may be realized. There is one caveat: the D. chrysippus population investigated by Ireri, Gordon and Smith (in prep.) is heavily parasitized by Spiroplasma; we do not know if uninfected females oviposit in similar fashion. In other words, it is possible that Spiroplasma manipulates the behaviour of its host to its own advantage.

I believe Idris and Hassan are right to dismiss the 'mimetic overload' hypothesis of Owen (1971) as an explanation of co-mimetic polymorphism; it does not fit the facts, especially as the geographical match of analogous morphs is so imperfect. However, in altogether dismissing Batesian mimicry in the paradoxical case of Hypolimnas misippus and D. chrysippus, Gordon et al. (2010) would disagree with Idris and Hassan; the former authors claim to show for the first time that Batesian mimicry functions intermittently but that other factors such as sexual, apostatic, and $r / K$ selection are also relevant to interpreting the polymorphism. The recurring mistake in the long debate on the misippus/chrysippus relationship has been the assumption that Batesian or Müllerian mimicry must be either the whole story or 
totally invalid. I acknowledge Idris and Hassan's claim that the mimicry at Khartoum, as in so many other places, appears problematical.

I think the authors are mistaken to dismiss the 'hybrid zone' hypothesis to account for polymorphism in D. chrysippus, for which there is much supporting evidence (Smith et al. 1997, 1998, Smith 2013). Although the hypothesis does not work for the Acraeas, $D$. chrysippus is a very different butterfly. The ecologies of $D$. chrysippus and the two Acraeas differ profoundly in several respects: in particular, the former is highly dispersive, migratory over long distances and polyphagous, whereas both Acraeas are monophagous and form tight colonies around their host plants from which females alone disperse short distances to found new colonies. There is no good reason to expect that one explanation for the evolution of their polymorphisms should apply to all three species. I profoundly disagree with the statement: 'Thus, in a habitat patch where the three species co-exist, a similar pattern of extinctionrecolonisation cycles will occur in the three sympatric populations.' (Idris and Hassan 2013: 10). Wherever the three species have been studied in sympatry (Dar es Salaam, Nairobi and Kampala), the main difference is that 'morph' frequencies in D. chrysippus fluctuate seasonally as its component semispecies migrate into and out of the study area, whereas in the Acraeas, morph frequencies are relatively stable within any one colony. The difference is explained by the fact that $D$. chrysippus 'morphs' are in reality incipient species, whereas in the Acraeas they are mere colour variants of a single species.

Again, in positing alternating extinction-recolonisation events interspersed by long periods of demographic stability as a mechanism for maintaining polymorphism, I feel it could work for the Acraeas but not for $D$. chrysippus in which polymorphisms are stabilized across wide areas. Idris and Hassan should acknowledge that the two Acraeas differ fundamentally in their respective mimicries of chrysippus. On the one hand, $A$. encedana is a convincing mimic throughout its range (Pierre, 1976), the biogeography of its morphs matching those of chrysippus from west, through east and down to southern Africa. On the other hand, A. encedon is more often than not an unconvincing mimic, and where it is so in Tanzania (Owen \& Smith, 1991), encedana is absent. The fundamental differences in polymorphism and mimicry between the two Acraeas, convincing Müllerian mimicry in A. encedana and feeble mimicry in A. encedon, argues against finding a single explanation for the origin of both.

With respect to the 'hybrid zone' hypothesis, Idris and Hassan (2013: 12) say 'a critical assumption of our hypothesis is that colour forms do not affect susceptibility to male killing, while a critical assumption of the 'hybrid zone' hypothesis is that colour forms do indeed vary in susceptibility. Thus, a clear test for both hypotheses [the alternative being their own] would be to investigate the relationship between colour pattern and Spiroplasma infection in D. chrysippus through a large study conducted within substantial spatial and temporal scales.' Such a study was in fact carried out by Smith (1975b) at Dar es Salaam, many years before the discovery of Spiroplasma, in which it was shown that $D$. c. dorippus was substantially less susceptible to allfemale brooding (subsequently proved to be caused by Spiroplasma) than D. c. chrysippus. Smith (1975b) proposed a model of which the prime feature was that D. c. dorippus carried a suppressor gene which enabled it to resist male-killing. An unpublished study under way at Nairobi (Ireri et al., in prep.) will endorse the Dar es Salaam finding in establishing that Spiroplasma infection is high in D. c. chrysippus but low in $D$. $c$. dorippus; indeed, the new evidence implies that Spiroplasma infection is essentially a symbiosis largely with D. c. chrysippus and hybrid forms of which it is one of the parents.

\section{References}

Duncan C.J., and P.M. Sheppard. 1965. Sensory discrimination and its role in the evolution of Batesian mimicry. Behaviour 24: 269-282. CrossRef

Edmunds M. 2000. Why are there good and poor mimics? Biological Journal of the Linnean Society 70: 459-466. CrossRef

Gordon I.J., Edmunds M., Edgar J.A., Lawrence J., and D.A.S. Smith. 2010. Linkage disequilibrium and natural selection for mimicry in the Batesian mimic Hypolimnas misippus (L.) in the Afrotropics. Biological Journal of the Linnean Society 100: 180194. CrossRef

Idris, E. and S.S.M. Hassan. 2013. Biased sex ratios and aposematic polymorphism in African butterflies: A hypothesis. Ideas in Ecology and Evolution 6: 5-16. CrossRef

Majerus, M.E.N. 1994. Ladybirds. London: Collins.

Owen, D.F. 1971. Tropical Butterflies. Oxford: Clarendon Press.

Owen D.F. and D.A.A. Smith. 1991. All-female broods and mimetic polymorphism in Acraea encedon (L.) (Lepidoptera: Acraeidae) in Tanzania. African Journal of Ecology 29: 241-247. CrossRef

Penney H.D., Hassall C., Skevington J.H., Abbott K.R., and T.N. Sherratt. 2012. A comparative analysis of the evolution of imperfect mimicry. Nature 483: 461-464. CrossRef

Pierre J. 1976. Polymorphisms et mimétisme chez deux espèces jumelles, Acraea encedon et A.encedana. Annales du Société Entomologique de France 12: 621-638. 
Smith D.A.S. 1975. All-female broods in Danaus chrysippus L. and their ecological significance. Heredity 34: 363-371. CrossRef

Smith D.A.S. 2013. African Queens and their Kin: a Neo-Darwinian Odyssey. Harpenden, UK: Brambleby Books Ltd.

Smith, D.A.S., Gordon, I.J., Depew, L.A. and Owen, D.F. 1998. Genetics of the butterfly Danaus chrysippus $\mathrm{L}$. in a broad hybrid zone, with special reference to sex ratio, polymorphism and intragenomic conflict. Biological of Journal Linnean Society $65: 1-40$.

Smith, D.A.S., Owen, D.F., Gordon, I.J. and Lowis, N.K. 1997. The butterfly Danaus chrysippus (L.) in East Africa: polymorphism and morph-ratio clines within a complex, extensive and dynamic hybrid zone. Zoological Journal of the Linnean Society 120: 51-78. CrossRef 